\title{
GAMMA IRRADIATION FOR PRESERVATION OF SURUHAN HERBS (Peperomia pellucida L. Kunth.) AND ITS BIOACTIVITY AGAINST L1210 LEUKEMIA CELLS
}

\author{
Ermin Katrin Winarno*, Susanto, and Hendig Winarno \\ Center for Isotopes and Radiation Application, National Nuclear Energy Agency (BATAN) \\ Jl. Lebak Bulus Raya, No. 49, Jakarta 12440, Indonesia \\ *Correspondence: Telp : 082138094517, email: e-mail:erminkk@batan.go.id
}

Online Published: December 31, 2020

DOI : 10.20961/jkpk.v5i3.46133

\begin{abstract}
Peperomia pellucida includes the Piperaceae family that has anti-cancer, antiinflammatory, antioxidant, and anti-microbial activities. Microbes easily contaminate dry herbs during storage, so special handling is needed. One of the preservation techniques is using irradiation technology. This technique can be used to extend the shelf life of herbal medicinal ingredients. This research aimed to study the effects of irradiation on the anti-cancer activity of $P$. pellucida leaves. $P$. pellucida leaves' dried powder was irradiated at doses of $5,7.5,10$, and 15 kGy. The anti-cancer activity test was carried out against L1210 leukemia cells. The un-irradiated irradiated samples were macerated successively with $n$-hexane, ethyl acetate, and ethanol, then be concentrated. The ethyl acetate extract was fractionated using silica gel column chromatography, obtained seven fractions. Their $\mathrm{IC}_{50}$ values $<20 \mu \mathrm{g} / \mathrm{mL}$, with fraction $\mathrm{F} 4$ was the most active fraction $\left(\mathrm{IC}_{50} 1.9 \mu \mathrm{g} / \mathrm{mL}\right)$. The result showed that gamma radiation at doses of $5-15$ kGy reduced their cytotoxic activity significantly. However, the fractions were still in the active category as anti-cancer ( $\mathrm{IC}_{50}$ values were $\left.<20 \mu \mathrm{g} / \mathrm{mL}\right)$.
\end{abstract}

Keywords: suruhan, Peperomia pellucida, gamma irradiation, L1210 leukemia cells

\section{INTRODUCTION}

As an agricultural country with thousands of types of plants, including medicinal plants, Indonesia has been used by their ancestors from generation to generation to improve public health. One of the Indonesian people's herbal medicinal ingredients is suruhan leaves (Peperomia pellucida L. Kunth) to cure illnesses. $P$. pellucida is a plant that is grown in Asian countries, used as a medicinal plant. This plant is known to benefit from analgesics, anti-inflammatory, antipyretic, antioxidant, antihyperglycemic, anti-hyper-uricemia, burn medication, and depressant effect, gastroprotective, hypotensive, anti-microbial, a lipase inhibitor, fibrinolytic and thrombocytic, anti-diarrhoea, headache due to fever, vertigo, and belly paint [1]. $P$. pellucida is also known to have been used to treat stomach upset, abscesses, acne, ulcers, colic, fatigue, gout [2][3]. The results of another study [4] showed that the ethanol extract and aqueous extract of $P$. pellucida leaves contained antioxidants (297 and 257 
$\mu \mathrm{g} / \mathrm{mL}$ ) and flavonoids (4.1 and 0.67 QE / g, respectively).

Researchers are now developing cytotoxic agents' discovery. The P. pellucida plant can be a chemopreventive agent based on its phytol content [5] [6]. The water extract of $P$. pellucida leaves contained antioxidants of $42.6 \mathrm{mg} / \mathrm{g} \mathrm{DW}$ [7]. Isolated 13 compounds from $P$. pellucida leaves; five of them were new compounds. Further, they tested the bioactivity of compound 1 and peperomin $\mathrm{E}$ against HL-60, MCF-7, and HeLa cells showed that those compounds had an inhibitory effect on the growth of three cancer cells with $\mathrm{IC}_{50}$ values ranging from $1.4-11.1$ $\mu \mathrm{M}[8]$.

the methanolic extract of $P$. pellucida leaves had the activity in inhibiting the growth of MCF-7 breast cancer and HeLa cervical cancer cells with $\mathrm{IC}_{50}$ values of 10.4 and 2.9 $\mu \mathrm{g} / \mathrm{mL}[9]$. Another study [10] showed that the ethanolic extract and water extract of $P$. pellucida leaves could inhibit the growth of HT-29 colon cancer cells with $\mathrm{IC}_{50}$ values of 129 and $170 \mu \mathrm{g} / \mathrm{mL}$, respectively [10]. Successive maceration of the dried powder of $P$. pellucida leaves with $n$-hexane, ethyl acetate, and ethanol showed that the three extracts inhibited the growth of L1210 leukemia cells with $\mathrm{IC}_{50}$ values of 10.9, 7.8, and $5.1 \mu \mathrm{g} / \mathrm{mL}$, respectively [11]. Based on the above studies results, $P$. pellucida leaves have big potential as an anti-cancer agent.

Post-harvest handling, until it is processed into dried herbal ingredients, is the important step so that the traditional medicines remain in a hygienic condition when they reach consumers. Various methods for preserving the herbal medicinal ingredients to extend their shelf life are cooling, freezing, heating, smoking, salting, adding additives, fumigation, and radiation techniques. Currently, radiation techniques by using ionizing radiation are proven to effectively reduce pathogenic microorganisms, prevent damage, prevent insect attack, delay germination, and inhibit the ripening process of fruits, vegetables, and other products have been routinely applied [12].

As part of nuclear technology, gamma radiation techniques have been developed to improve food safety, including herbal medicine. In recent years, gamma-ray irradiation techniques to extend herbal ingredients / herbal medicines' shelf life have increased. More than 30 herbal medicine companies have utilized gamma irradiation to pasteurize herbal ingredients to extend their shelf life [13]. According to the Regulation of The National Agency for Food and Drug Administration and Control (NAFDAC) No. 3 the year 2018, irradiation at a dose up to $10 \mathrm{kGy}$ can reduce certain pathogenic microbes and insect disinfestation [14]. Throughout 2017, 200 tons of commodities classified as herbal ingredients/ herbal medicines irradiated at the Gamma Merah Putih Irradiator belong to BATAN Indonesia, 531 tons in 2018426 tons in 2019. Although many herbal medicine industries have long used gamma irradiation, unfortunately, there is limited information on the radiation effect on dried $P$. pellucida leaves. There have been no previous research results that studied especially the effect of gamma irradiation on $P$. pellucida leaves' efficacy.

In this study, $P$. pellucida was chosen because it has been widely used as herbal medicine. In the previous [15], gamma irradiation has been reported at doses of 2.5- 
$10 \mathrm{kGy}$ on the angiotensin-converting enzyme (ACE) inhibitory activity, antioxidant activity, total phenolic, and flavonoid contents in dried $P$. pellucida leave. The result showed that irradiation at a dose of $7.5 \mathrm{kGy}$ has no significant difference in antioxidant activity and ACE inhibitory activity, and total phenolic and flavonoid contents. Nevertheless, there were no data and information about gamma irradiation's effect on P. pellucida herbs' anticancer properties.

The research aimed to study the effects of irradiation toward its anti-cancer activity on the dried powder of $P$. pellucida leaves preserved by gamma irradiation. The anti-cancer activity changed due to gamma irradiation, which was studied based on the cytotoxic activity expressed as the halfmaximum inhibitory concentration ( $\left.\mathrm{IC}_{50}\right)$ value of irradiated dried powder $P$. pellucida leaves against L1210 leukemia cells compared to the control sample. The extractor fraction is declared to has a cytotoxic activity if it has an $\mathrm{IC}_{50}$ value of $\leq 20$ $\mu \mathrm{g} / \mathrm{mL}$ [16]. This data and information are necessary for clarifying whether the gamma irradiation can eliminate its cytotoxic activity or not, since it is beneficial for Herbal Medicine Industries to decide the suitable irradiation doses, NAFDAC to formulate the regulation, and consumer protection.

\section{METHODS}

\section{Materials}

The fresh suruhan leaves (Peperomia pellucida L. Kunth.) was obtained from Indonesian Research Institute for Medicinal Crops and Aromatic (Balai Penelitian
Tanaman Obat dan Aromatik, BALITTRO) JI. Tentara Pelajar No. 3A, Bogor - West Java and plant determination was done by Research Center for Biology-The Indonesian Institute of Science (Pusat Penelitian Biologi - LIPI), Cibinong, Bogor.

Other materials were $n$-hexane, ethyl acetate, ethanol, methanol, distilled water, $\mathrm{NaHCO}_{3}$, calf bovine serum (Gibco), L1210 leukemia cells, which originally obtained from The Institute of Physical and Chemical Research (RIKEN) Japan, RPMI 1640 (Media Roswell Park Memorial Institute 1640), tryphan blue $1 \%$, celite 545 , chloroform, silica gel 70-230 mesh size (Merck).

\section{Equipment}

Column Chromatography, thin layer chromatography chamber, of the rotary evaporator (Buchi R-22 SE; five L capacity) and (Buchi R-111; one L capacity), ultrasonicator (NEY), $\mathrm{CO}_{2}$ incubator, light microscope, Neubauer Improved hemocytometer, tissue culture multiwall plate, analytical scales (Mettler Taledo), sero cluster plate, blender (Miyako), UV lamps 254 and $366 \mathrm{~nm}$ (Camag), oven, aluminum foil, micropipettes, electric heater, vacuum desiccator, filter paper, and glassware.

\section{Sample Preparation}

Fresh $P$. pellucida leaves were washed and dried at room temperature until their water content $3.3 \%$. The dried leaves were made into a coarse powder, wrapped in plastic bags, and weighed $200 \mathrm{~g}$, respecttively. 


\section{Samples Irradiation}

The dried powder of $P$. pellucida leaves wrapped in a PE plastic bag was placed in a cardboard box then irradiated with gamma rays at various doses of $5,7.5,10$, and 15 kGy (2 replicates for each dose). The irradiation was conducted at the Center for Isotopes, and Radiation Application-BATAN, Jakarta-Indonesia, with a gamma source was Co-60.

\section{Extract preparation}

The un-irradiated (control) and irradiated samples@ @200 g were successively macerated with $n$-hexane, ethyl acetate, and ethanol. Each sample was macerated repeatedly five times for each type of solvent to ensure that all components are extracted into the solvent. The macerate is filtered, evaporated, dried with a vacuum pump in a desiccator, and then weighed. In this study, only ethyl acetate extract was selected, then further fractionated by column chromatography.

\section{Fractionation of ethyl acetate extract}

A total amount of $1.0 \mathrm{~g}$ of ethyl acetate extract from an unirradiated (control) sample was dissolved in ethyl acetate, then mixed with $30 \mathrm{~g}$ of cellite 545 , evaporated to get a dry powder, then fractionated using column chromatography with the stationary phase of silica gel 70-230 mesh $(30 \mathrm{~g})$. The used mobile phase was started from n-hexane, a mixture of n-hexane-ethyl acetate, and finally methanol. The fractions with a similar spot pattern on the TLC silica gel plat were combined, evaporated by the vacuum-rotary evaporator, and then further dried by a vacuum pump in the desiccator. Furthermore, the ethyl acetate extracts from irradiated $P$. pellucida leaves with various doses were also fractionated in the same manner as fractionation of the control sample.

\section{Bioassay on L1210 leukemia cells}

The cytotoxic activity test of the ethyl acetate extract fraction against leukemia L1210 cells was carried out with previous studies [17] [18]. The sample concentration variation was $0.5 ; 1,2,4$. and $8 \mu \mathrm{g} / \mathrm{mL}$ using Roswell Park Memorial Institute 1640 media (RPMI 1640) with $5 \%$ bovine fetal serum. Incubation was carried out in a $5 \% \mathrm{CO}_{2}$ incubator at $37^{\circ} \mathrm{C}$ for 48 hours.

\section{Calculation of $I_{50}$ value and data analysis}

The number of living cells was counted under the microscope, then converted to the number of dead cells to get the inhibition percentage. The half value of the maximum inhibitory concentration (IC50), which is the sample's concentration, states the ability to inhibit $50 \%$ of cancer cell proliferation. It can be calculated using a linear regression equation between the probit percentage of inhibition (Y-axis) versus the sample concentration logarithm (X-axis). Analyzed statistically using one-way analysis of variance (ANOVA)[17][18].

\section{RESULTS AND DISCUSSION}

\section{Extract and fraction}

From a total amount of $200 \mathrm{~g}$ of dried powder of $P$. pellucida leaves with a water content of $3.3 \%$, the obtained extracts from 
unirradiated and irradiated samples are presented in Table 1.

Table 1. The yield of extract from the unirradiated (control) and irradiated $P$. pellucida leaves

\begin{tabular}{cccccc}
\hline \multirow{2}{*}{\begin{tabular}{c} 
Radiation $\begin{array}{c}\text { Wose } \\
\text { doGy) }\end{array}$ \\
\cline { 2 - 5 }
\end{tabular}} & \multicolumn{3}{c}{ Weight of extract } & $\begin{array}{c}\text { Weight of } \\
\text { total } \\
\text { extract }(\mathrm{g})\end{array}$ & $\begin{array}{c}\text { Rende- } \\
\text { men } \\
(\%)\end{array}$ \\
\hline 0 & 4.5 & 8.5 & 10.1 & 23.1 & 11.6 \\
acthyl & Ethanole & & & \\
5 & 3.1 & 7.7 & 7.7 & 18.4 & 9.2 \\
7.5 & 3.8 & 4.5 & 9.6 & 17.8 & 8.9 \\
10 & 3.5 & 6.2 & 9.5 & 19.2 & 9.6 \\
15 & 3.7 & 8.3 & 8.1 & 20.0 & 10.0 \\
\hline
\end{tabular}

Table 1 shows that all of the extract's weight tends to decrease compared to the extract from the control/un-irradiated sample. In the total yield, it was also seen that the irradiated samples tended to decrease compared to the control sample. Based on the previous study [11], $n$-hexane, ethyl acetate, and ethanol extracts from unirradiated $P$. pellucida leave had cytotoxic activity against $L 1210$ leukemia cells with $I_{50}$ values of $10.9,7.8$, and $5.1 \mu \mathrm{g} / \mathrm{mL}$. Accordingly, in this study, the ethyl acetate extract of $P$. pellucida leaves was selected to be fractionated using column chromatography and obtained seven fractions (F1 - F7) with the weight of each fraction are presented in Table 2.

Table 2. Weight of fractions of ethyl acetate extract from P.pellucida leaves

\begin{tabular}{cccccccc}
\hline \multirow{2}{*}{$\begin{array}{c}\text { Radiation } \\
\text { Dose }\end{array}$} & \multicolumn{6}{c}{ Fraction weight (mg) of ethyl acetate extract } \\
\cline { 2 - 8 } & F1 & F2 & F3 & F4 & f5 & F6 & F7 \\
\hline 0 kGy & 42 & 107 & 182 & 180 & 47 & 254 & 65 \\
$5 \mathrm{kGy}$ & 22 & 32 & 29 & 36 & 181 & 40 & 274 \\
$7.5 \mathrm{kGy}$ & 16 & 30 & 19 & 65 & 183 & 146 & 107 \\
$10 \mathrm{kGy}$ & 30 & 43 & 23 & 41 & 64 & 122 & 127 \\
$15 \mathrm{kGy}$ & 13 & 23 & 17 & 16 & 33 & 74 & 97 \\
\hline
\end{tabular}

From Table 2, it can be seen that generally, the fraction weight tended to decrease due to increasing the irradiation doses. Still, oppositely for fractions 5 and 6 , the weight increased at doses of 5 and 7.5 kGy, while for fraction seven, the weight increases at doses of 5, 7.5, and $10 \mathrm{kGy}$. This change in the solubility of components was easy or otherwise difficult to disperse into the solvents during maceration.

\section{Cytotoxic activity of fraction}

The cytotoxic activity test of F1 - F7 of ethyl acetate extract from the control sample against L1210 leukemia cells were shown in Figure 1. Based on the linear regression.

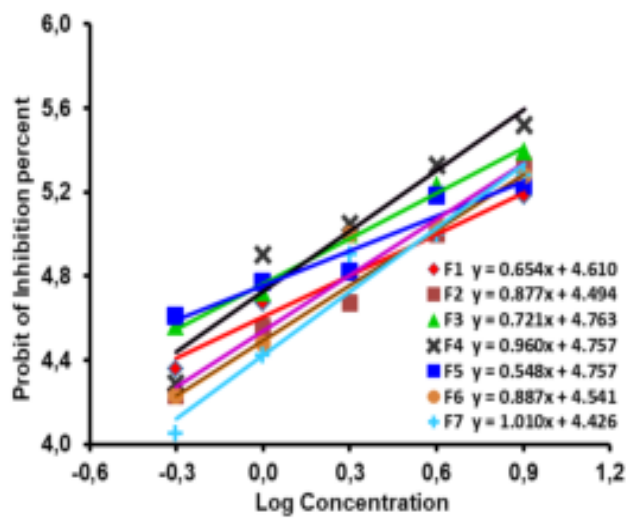

Figure 1. Linear regression curve between probit of inhibition percentage vs. log concentration of F1-F7 of ethyl acetate from un-irradiated $P$. pellucida leaves

The equation in Figure 1, then the $I_{50}$ value was calculated, and the results were presented in Table 3. Table 3 shows that the $\mathrm{IC}_{50}$ values of all fractions (F1 - F7) had $<20$ $\mu \mathrm{g} / \mathrm{mL}$. Based on the provisions of the US $\mathrm{NCl}$ [19]; the extract has the potential to be anti-cancer if the IC50 value is less than 20 $\mu \mathrm{g} / \mathrm{ml}$. means to be the result that all fractions. 
Table 3. The $\mathrm{IC}_{50}$ value of $\mathrm{F} 1-\mathrm{F} 7$ of ethyl acetate extract from unirradiated $P$. pellucida leaves

\begin{tabular}{ccc}
\hline Fraction & Linier regression & $\begin{array}{c}\mathrm{IC}_{50} \text { values } \\
(\mathrm{mg} / \mathrm{ml})\end{array}$ \\
\hline F1 & $\mathrm{y}=0.654 \mathrm{x}+4.610$ & 4.0 \\
F2 & $\mathrm{y}=0.877 \mathrm{x}+4.494$ & 3.8 \\
F3 & $\mathrm{y}=0.721 \mathrm{x}+4.763$ & 2.1 \\
F4 & $\mathrm{y}=0.960 \mathrm{x}+4.729$ & 1.9 \\
F5 & $\mathrm{y}=0,548 \mathrm{x}+4.747$ & 2.8 \\
F6 & $\mathrm{y}=0.887 \mathrm{x}+4.541$ & 3.3 \\
F7 & $\mathrm{y}=1.010 \mathrm{x}+4.428$ & 3.7 \\
\hline
\end{tabular}

Ethyl acetate extract of $P$. pellucida leaves was very active in inhibiting L1210 leukemia cells; this meant that all fractions had potential as anti-cancer. The qualitative identification of secondary metabolite content was also supported by Andriani et al. [20] that the plants contained flavonoids, triterpenoids, steroids, and saponins tannins are believed to affect their cytotoxic activity. Meanwhile, Yusuf et al. [15] founded that irradiation at a dose of $10 \mathrm{kGy}$ could cause significant changes in antioxidant activity, phenolic levels, and flavonoids levels in $P$. pellucida leaves. The bioactivity of these $P$. pellucida leaves was also supported by the study of $\mathrm{Xu}$ et al. that the peperomin $\mathrm{E}$ compound isolated from $P$. pellucida leaves could inhibit cancer cells' growth HL-60, MCF-7, and HeLa with $\mathrm{IC}_{50}$ values range from 1.8 to $11.1 \mu \mathrm{g} / \mathrm{mL}$ [8].

$P$. pellucida leaves contained phytol as a primary compound, a terpene compound, and acted as an anti-cancer [9]. Based on the description above, it was assumed that the compounds of the flavonoids, triterpenoids, steroids, saponins, and tannins, and phytol compounds caused $P$. pellucida leaves to be very active in inhibiting the growth of L1210 leukemia cells. In Table 2, from 7 fractions, F4 was the most active fraction with the lowest $\mathrm{IC}_{50}$ value of $1.9 \mu \mathrm{g} / \mathrm{mL}$. All F4 ethyl acetate extracts from irradiated P. pellucida leaves were tested for their cytotoxic activity. The results of this test are presented in Figure 2. In contrast, the calculated $\mathrm{IC}_{50}$ values based on Figure 2 were shown in Table 4.

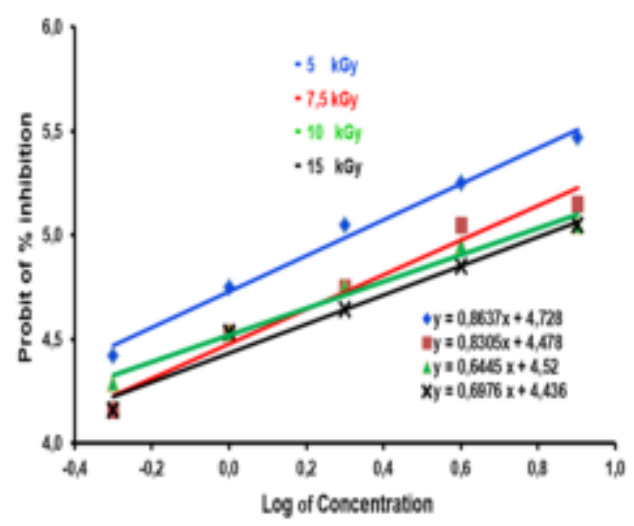

Figure 2. Linear regression curve between probit of percentage inhibition vs. log F7 concentration of ethyl acetate extract derived from irradiated samples

Analysis using one-way ANOVA with a 95\% confidence level showed that gamma irradiation from the doses of 5 to $15 \mathrm{kGy}$ increased the $\mathrm{IC}_{50}$ value significantly, which meant cytotoxic activity decreased. However, the decrease did not eliminate their activities; it can be seen that the $\mathrm{IC}_{50}$ values were still low $(<20 \mu \mathrm{g} / \mathrm{ml})$, between $2.1-6.4 \mu \mathrm{g} / \mathrm{mL}$ (Table 4). Fraction 4 was still in the active category as anti-cancer.

Table 4. The $\mathrm{IC}_{50}$ value of fraction 4 of ethyl acetate extract from unirradiated and gamma-irradiated $P$. pellucida leaves

\begin{tabular}{cc}
\hline $\begin{array}{c}\text { Irradiation Dose } \\
(\mathrm{kGy})\end{array}$ & $\begin{array}{c}\mathrm{IC}_{50} \text { values of } \mathrm{F} 4 \\
(\mathrm{mg} / \mathrm{ml})\end{array}$ \\
\hline 0 & $1.9^{\mathrm{a}}$ \\
5 & $2.1^{\mathrm{b}}$ \\
7.5 & $4.3^{\mathrm{c}}$ \\
10 & $5.6^{\mathrm{d}}$ \\
15 & $6.4^{\mathrm{e}}$ \\
\hline
\end{tabular}




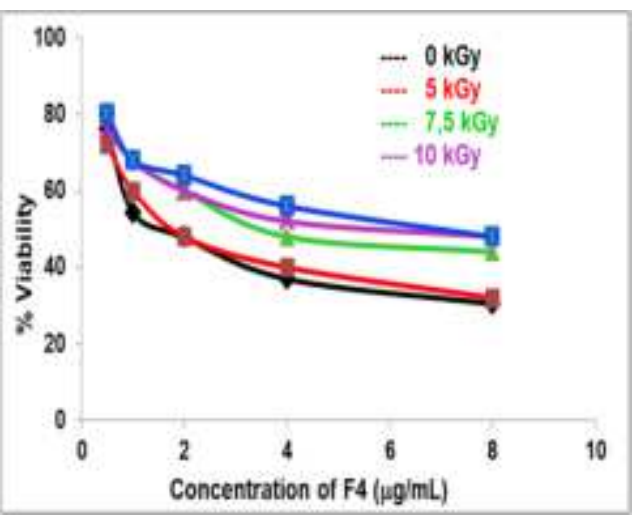

Figure 3. Graph of average viability of L1210 leukemia cell vs. F4 concentration

Furthermore, in Figure 3, it was clear that the effect of decreasing cell viability of L1210 cells by $\mathrm{F} 4$ at all sample concentrations decreased with increasing irradiation dose (Figure 3). However, the irradiated samples at doses of 5 - 15 kGy still had high cytotoxic activity. Based on the results, it can be stated that $P$. pellucida herbs can be preserved using the gamma irradiation technique as recommended by the NADFC [14] for dry herbs with the maximum irradiation dose of $10 \mathrm{kGy}$.

\section{CONCLUSION}

Gamma irradiation on the dried powder of Peperomia pellucida leaves at doses of 5 15 kGy has decreased ethyl acetate extract's cytotoxic activity against L1210 leukemia cells, which is shown on the increasing of $\mathrm{IC}_{50}$ value significantly. However, the decrease of their activity did not damage the activity of $P$. pellucida leaves, proved still to have the $\mathrm{IC}_{50}$ value $<20 \mu \mathrm{g} / \mathrm{mL}$. It can be concluded that the use of gamma irradiation can still be done up to a dose of $10 \mathrm{kGy}$ according to the NAFDAC Regulation No.3 the year 2018. Fraction 4 (F4) of the ethyl acetate extract of $P$. pellucida leaves was the most active fraction among the seven fractions with an $\mathrm{IC}_{50}$ value of $1.69 \mu \mathrm{g} / \mathrm{mL}$, and it can be used as a comparative fraction to study the effect of radiation on the $P$. pellucida herbs.

\section{ACKNOWLEDGEMENTS}

Thanks to the Center for Isotopes Radiation Application - BATAN for supporting this study and "Karet Alam" Irradiator Facility - CIRA - BATAN for irradiating the samples.

\section{REFERENCES}

[1] N. Sujnan, S. Satish, K. Hegde and A. R. Shabaraya, "A Review on Pharmacological Activities of the Plant Peperomia Pellucida. L," Int. J. Pharma Chem. Res., vol. 4, no. 2, pp. 106-110, 2018.

Google Scholar

[2] E. Sitorus, L. I. Momuat, and D. G. Katja, "Aktivitas Antioksidan Tumbuhan Suruhan (Peperomia pellucida [L.] Kunth)," J. IIm. Sains, vol. 13, no. 1, p. 80, 2013,

DOI: 10.35799/jis.13.1.2013.2116

[3] N. Yunarto, H. M. Ar Rossyid, and L. A. Lienggonegoro, "Effect of Ethanolic Leaves Extract of Peperomia pellucida (L) Kunth as Antimalarial and Antioxidant," Media Penelit. dan Pengemb. Kesehat., vol. 28, no. 2, pp. 123-130, 2018, DOI: $10.22435 / \mathrm{mpk} . v 28 \mathrm{i} 2.132$

[4] E. Ukieyanna, Aktivitas Antioksidan, Kadar Fenolik dan Flavonoid Total Tumbuhan Suruhan (Peperomia pellucida L. Kunth)," 2012.

Google Scholar

[5] Raghavendra H. L. and P. Kekuda T.R., "Ethnobotanical Uses, Phytochemistry and Pharmacological Activities of Peperomia Pellucida (L.) 
Kunth (Piperaceae) - a Review," Int. J. Pharm. Pharm. Sci., vol. 10, no. 2, p. 1, 2018,

DOI: 10.22159/ijpps.2018v10i2.23417

[6] I. G. A. A. Kartika, M. Insanu, D. Safitri, C. A. Putri, and I. K. Adnyana, "New update: Traditional uses, phytochemical, pharmacological and toxicity review of peperomia pellucida (I.) kunth," Pharmacologyonline, vol. 2016, no. 2, pp. 30-43, 2016.

Google Scholar

[7] V. Samila, Indrawati, and Refilda, "Optimasi Ekstraksi Antioksidan Total dalam Tumbuhan Suruhan (Peperomia pellucida L. Kunth) Menggunakan Ultrasonik dan Penen-tuan Kadarnya Dengan Metode DPPH," J. Kim. Unand, vol. 5, no. 2303, pp. 44-51, 2016.

Google Scholar

[8] S. Xu, N. Li, M. M. Ning, C. H. Zhou, Q. R. Yang, and M. W. Wang, "Bioactive compounds from Peperomia pellucida," J. Nat. Prod., vol. 69, no. 2, pp. 247-250, 2006,

DOI: $10.1021 / \mathrm{np} 050457 \mathrm{~s}$

[9] L. S. Wei, W. Wee, J. Y. F. Siong, and D. F. Syamsumir, "Characterization of anti-cancer, anti-microbial, antioxidant properties and chemical compositions of Peperomia pellucida leaf extract," Acta Med. Iran., vol. 49 , no. 10 , pp. 670-674, 2011.

DOI: $10.1021 / \mathrm{np} 050457 \mathrm{~s}$

[10] N. Moorthi, K. Vasantha, and A. Maruthasalam, "In vitro Evaluation of Cytotoxic Properties of Peperomia pellucida ( L .)," Biosci. Discov., vol. 9, no. 3, pp. 344-355, 2018.

Google Scholar

[11] J. G.Bekesi, G. S. Arneault, L. Walter, \& J. F.Holland, " Immunogenicity of leukemia L1210 cells after neuraminidase treatment". Journal of the National Cancer Institute, vol. 49, no. 1, pp. 107-118,1972.

DOI:10.1093/jnci/49.1.107

[12] N. Asiah, K. N. Kusaumantara, and A. N. Annisa, "Iradiasi Bahan Pangan: Antara Peluang dan Tantangan untuk Optimalisasi Aplikasinya Food Irradiation: Between Opportunity and Challanges for Optimizing Applications," pp. 25-36, 1907. Jurnal IImiah Aplikasi Isotop dan Radiasi (A Scientific Journal for The Applications of Isotopes and Radiation) vol. 15, no. 1, Juni 2019.

DOI: 10.17146/jair.2019.15.1.4703

[13] M. Handayani and H. Permawati, "Gamma irradiation technology to preservation of foodstuffs as an effort to maintain quality and acquaint the significant role of nuclear on food production to Indonesia society: A Review," Energy Procedia, vol. 127, pp. 302-309, 2017.

DOI: 10.1016/j.egypro.2017.08.112

[14] Kepala BPOM, "Peraturan Badan Pengawas Obat Dan Makanan Nomor 3 Tahun 2018 Tentang Pangan Iradias," BPOM RI, vol. 2010, pp. 116, 2017.

Google Scholar

[15] M. S. Yusuf I. Wulandari, L. Amelia, Katrin, A. Novianti, Rissyelly, A. Munim, "Effect of gamma irradiation on suruhan (Peperomia pellucida (L.) Kunth) herb powder, " Pharmacogn. J., vol. 9, no. 2, pp. 239-243, 2017, DOI: $10.5530 /$ pj.2017.2.40

[16] E. S. A. Hameed, S. A. Bazaid, M. M. Shohayeb, M. M. El-Sayed and E. A. El-Wakil, "Phytochemical Studies and Evaluation of Antioxidant, Anticancer and Antimicrobial Properties of Conocarpus erectus L. Growing in Taif, Saudi Arabia," European J. Med. Plants, vol. 2, no. 2, pp. 93-112, 2012, DOI: 10.9734/EJMP/2012/1040 
[17] E. K. Winarno, H. Winarno, and Susanto, "Antiproliferative activity of extracts and fractions from irradiated Curcuma zanthorrhiza rhizomes against mouse leukemia and human cancer cell lines," Atom Indones., vol. 45, no. 3, pp. 159-164, 2019, DOI: 10.17146/aij.2019.957

[18] E. K. Winarno, I. R. Reswari, Susanto, and $\mathrm{H}$. Winarno, "Pengaruh Iradiasi Gamma Terhadap Solanum Nigrum L Dan Efeknya Sebagai Anti Kanker," J. Sains dan Teknol. Nukl. Indones., vol. 19, no. 1, p. 21, 2018,

DOI: 10.17146/jstni.2018.19.1.3693
[19] V. Kuete, E. A. Seo, B. Krusche, M. Oswald, B. Wiench, S. Schroder, H. J. Greten, I. S. Lee and T. Efferth, "Cytotoxicity and pharmacogenomics of medicinal plants from traditional Korean medicine," Evidence-based Complement. Altern. Med., vol. 2013, 2013, DOI: $10.1155 / 2013 / 341724$

[20] Y. Andriani, N.M. Ramli, D.F. Syamsumir, M.N.I. Kassim, J. Jaafar, N.A. Aziz, L. Marlina, N.S. Musa, and $\mathrm{H}$. Mohamad "Phytochemical analysis, antioxidant, antibacterial and cytotoxicity properties of keys and cores part of Pandanus tectorius fruits," Arab. J. Chem., vol. 12, no. 8, pp. 3555-3564, 2019,

DOI: 10.1016/j.arabjc.2015.11.003 